\title{
Perceptions of termites in urban areas of semiarid Brazil
}

\author{
Maria Avany Bezerra-Gusmão ${ }^{1,2 *}$ \\ Ana Marcia Barbosa-Silva ${ }^{1}$ \\ Antonio Paulino de Mello ${ }^{1}$ \\ José Valberto de Oliveira ${ }^{2}$ \\ Adrianne Teixeira Barros ${ }^{2}$ \\ State University of Paraíba \\ ${ }^{1}$ Post-Graduate Program in Ecology and Conservation \\ Avenida das Baraúnas, 351, CEP 58109-790, Campina Grande - PB, Brazil \\ ${ }^{2}$ Departament of Biology \\ * Corresponding Author \\ bezerra.gusmao@uepb.edu.br
}

Submetido em 16/04/2014

Aceite para publicação em 03/07/2014

\section{Resumo}

Percepção sobre os cupins em área urbana no semiárido do Brasil. Os cupins estão presentes no cotidiano da maioria das pessoas, embora eles geralmente provoquem um sentimento de forte aversão, especialmente em populações de áreas urbanas. O estudo buscou analisar a percepção de populações humanas em relação a esses insetos em área urbana, nas cidades de Fagundes (A1) e Pocinhos (A2), no estado da Paraíba, Brasil. Questionários semiestruturados foram respondidos por 100 residentes nas duas cidades em situações sincrônicas e diacrônicas. Apesar de a maioria dos entrevistados (A1 - 64\% e A2 - 72\%) reconhecer morfologicamente os cupins, esses mostraram desconhecer o papel ecológico desses animais nos ambientes natural e urbano, com exceção de aceitar sua utilização no tratamento de oito tipos de enfermidades humanas. Do total dos entrevistados, $22 \%$ em A2 e $8 \%$ em A1 acreditam que os cupins fazem coisas ruins, cheiram mal e têm pus. Os métodos indicados para eliminação dos cupins do ambiente estiveram atrelados à crença popular desses animais trazerem "má sorte". Destaca-se, assim, a importância de estudos acadêmicos que venham esclarecer tais relações à população, ressaltando o papel ecológico dos cupins no ambiente, ao mesmo tempo em que se desmitifica o fato de um cupim ser visto apenas como elemento que causa destruição e medo.

Palavras-chave: Conhecimento popular; Cupins; Insetos; Mitos; Zooterapia

\section{Abstract}

Termites are present in the daily life of most people, although they usually evoke a sense of strong dislike, especially in populations of urban areas. This study sought to analyze the perception of these insects in human populations in urban areas in the towns of Fagundes (A1) and Pocinhos (A2), in Paraíba state, Brazil. Semistructured questionnaires were answered by 100 residents in these two areas, following both synchronic and diachronic situations. In spite of the fact that most of the interviewees (64\% in A1 and $72 \%$ in A2) were able to identify termites by morphology and had knowledge of use for treating eight types of human diseases, very few understood their ecological roles in nature. Attempts to eliminate termites from human environments were 
linked to the popular belief that these animals are sources of bad luck. Twenty-two percent of the interviewees in A1 and 8\% in A2 believe that termites are capable of doing damage or harm, of having a foul smell, and/or of containing pus.In this sense, academic studies are important because they can inform people of the ecological roles of termites in natural and urban environments, while demystifying the termite as an agent of fear and destruction.

Key words: Insect; Myths; Popular knowledge; Termites; Zootherapy

\section{Introduction}

The collective knowledge in human communities of biodiversity within their surrounding environments is intimately linked to how they think about, sense, and act in relation to the components of the living world (COSTA-NETO, 2002). In this context, studies of how insects are perceived, classified, and utilized by human populations lie within the domain of Ethnoentomology (POSEY, 1986; COSTA-NETO, 2004). The perception that an ethnic group has about a given living organism (in this case, invertebrates/insects) will directly influence the use of such organisms in rituals, and in productive and cultural activities (FAIRHEAD; LEACH, 1999). A person's set of positive (attractive) and negative (repulsive) feelings toward an organism is influenced by biocultural aspects, as both individual emotions and cultural traditions can promote a predisposition that interferes with processes of perception (BALLONE, 1999). Generally, individuals are familiar with invertebrates/insects because some cause disease. Empathy, appreciation and considerable knowledge are needed in order for the general public to respond appropriately to an encounter with insects (LAUCK, 2002).

Termites are a constant presence in the lives of human beings, and thus, it is important to understand the psycho-social relationships that develop in an ethnoentomological context. When termites are involved, the mental image projected is almost always that of a pest that must be combated (BEZERRA-GUSMÃO et al., 2010). Globally, these insects are best known for the economic damage they can cause in both natural and urban environments (SU; SCHEFFRAHN, 1990; MILANO; FONTES, 2002), and their presence is usually easily perceptible due to the covered and tube-like trails they construct (TREVISAN et al., 2003).
However, most people are unaware of the important ecological functions these animals have as primary consumers and decomposers (BIGNELL; EGGLETON, 2000). Termites influence the maintenance and recuperation of soil porosity, humidity, and mineral cycling, and generally improve the physical and chemical properties of the soil, all of which lead to improved agricultural production (FAIRHEAD; LEACH, 1999; BEZERRA-GUSMÃO et al., 2011).

According to Morales et al. (1997), acquired attitudes of humans toward animals are influenced by numerous aspects, including the animal's appearance and abundance, and tactile and visual nature; attitudes can also be influenced by human beliefs in terms of spirituality, concepts involving cleanliness, perception of benefits or losses imposed, discomfort generated, and knowledge or ignorance of the animal in general. BertiFilho and Fontes (1996) noted that human illnesses or allergies do not seem to be caused by termites. Damage caused by these insects is typically strictly economic in nature, although this damage can greatly affect people, especially urban dwellers. Milano and Fontes (2002) elaborated that damage caused by noxious creatures is not merely economic, but can also result in social, cultural, and psychological disruptions.

There have been several studies in Brazil focusing on folk knowledge in the fields of ethnozoology and zootherapy (COSTA-NETO, 1997; 1998; 1999; COSTA-NETO; PACHECO, 2004; SAMPAIO et al., 2006; ALVES; ROSA, 2006; ALVES, 2007; ALVES et al., 2007), but specific information about human relationships with termites, whether linked to entomotherapy or ethnoecology and in urban or arid regions, is still quite scarce. A number of studies have examined the ethnotherapeutic uses of termites (LAGES FILHO, 1934; BRANCH; SILVA, 1983; COSTA-NETO; PACHECO, 2004; ALVES, 2009; ALVES; DIAS, 2010), 
although these applications have not been directly evaluated or studied in urban areas.

The present study sought to examine and analyze public perception and popular knowledge of termites in two urban communities (Fagundes and Pocinhos), in order to determine the cultural status of these insects as useful and/or as negatively prejudged by humans.

\section{Materials and Methods}

\section{Study area}

The study was composed in the municipal centers of Fagundes ( $\left.7^{\circ} 20^{\prime} 45^{\prime} \mathrm{S} / 35^{\circ} 47^{\prime} 51^{\prime \prime} \mathrm{W}\right)$ and Pocinhos $\left(7^{\circ} 04^{\prime} 36^{\prime \prime} \mathrm{S} / 36^{\circ} 03^{\prime} 40^{\prime \prime} \mathrm{W}\right)$, which are located in the inland region of Paraíba state, Brazil (Figure 1). The municipality of Fagundes occupies a territorial area of $189 \mathrm{~km}^{2}$, with a population of 11,409 (IBGE, 2010); it is situated at $505 \mathrm{~m}$ above sea level and has an average annual rainfall of $981.3 \mathrm{~mm}$ and average annual temperature variying between $24^{\circ}$ and $28^{\circ} \mathrm{C}$ with an average relative humidity of $73 \%$ (SUDENE, 1990). Due to strong immigration from rural areas, the population of Pocinhos has been steadily increasing, especially in peripheral urban areas. The municipality covers $630 \mathrm{~km}^{2}$ and has 17,020 inhabitants (IBGE, 2010). The average annual temperature is $23^{\circ} \mathrm{C}$, with little variation during the year, and the annual rainfall varies between 400 and $600 \mathrm{~mm}$ (RIBEIRO, 2003).

\section{Data collection and analysis}

Twenty-five men and 25 women above 18 years of age were randomly selected and interviewed in each municipality using semi-structured questionnaires (BERNARD, 1994) applied to current and historical contexts between August/2010 and July/2011. The questions sought to elucidate popularly held knowledge and beliefs concerning termites in the study area. The issues addressed were as follows: whether respondents knew of termites, whether they knew termites were insects, if there were termites in their homes, which types were present, how to control infestations, and which methods of control were used. Ecological questions were also raised, e.g., the location of termite habitats, whether the termite population is stable or has increased compared to prior years, and whether termites and/or their nests were used for medicinal purposes (and how they were used).

Interviewees were shown photographs depicting different phases of the termite lifecycle (e.g., nymphs, immatures, and winged or reproductive forms). Photographs of various termite species as well as other animal taxa, including ant species in various stages (adult ants, winged ants, and ants in different reproductive

FIGURE 1: Locations of the towns of Pocinhos and Fagundes in Paraíba state, northeastern Brazil (Adapted from NOBREGA et al., 2011).

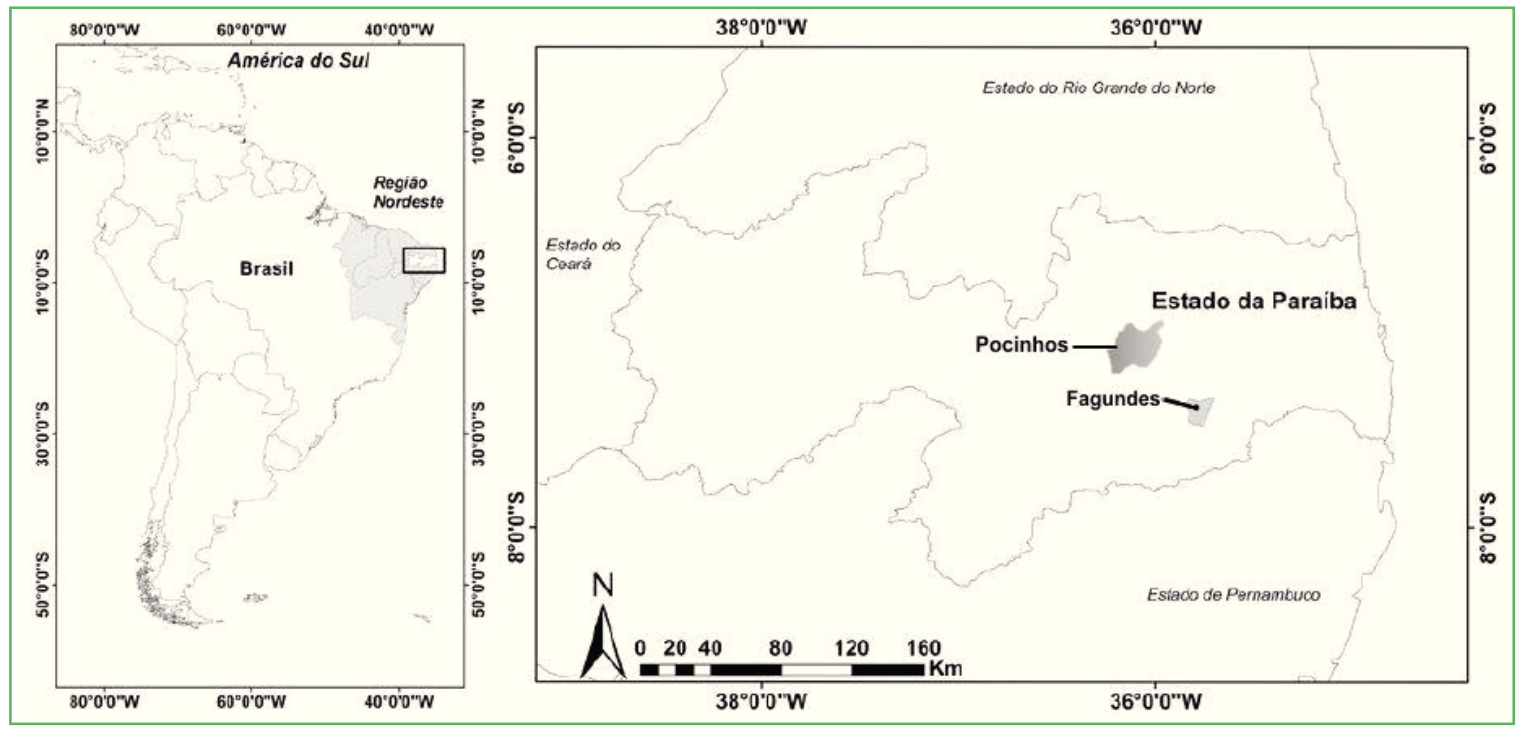


stages) were also shown (Figure 2). Pictures of ants were used because people sometimes confuse termites with alate ants (BEZERRA-GUSMÃO et al., 2010; ULYSSÉA et al., 2010). These tests sought to record public perception of termites and insects via exposure to photographic images. The images shown to interviewees depicting different phases of the lifecycle of termites and other taxa were technically correct according to current scientific nomenclature.

The sociocultural profiles of the participants included: 41 farmers, 14 maids, nine autonomous workers, seven public employees, six retirees, five service workers, four salespersons, four students, three grammar school teachers, two chauffeurs, two stonemasons, one carpenter, one baker, and one electrician. Of these, 11 had finished grammar school and 40 had not, 27 had completed middle school and five had not, and four had completed high school. Thirteen of the interviewees could only sign their name. Their ages varied between 19 and 86 years old (Fagundes), and 19 and 78 years old (Pocinhos).
The participants were informed of the objectives of the research project before initiation of interviews. Whenever possible, the interviews were tape-recorded. The resulting ethnographic reports and photographic records were stored in the Ethnoecology Nucleus of the Biology Department at Paraíba State University (UEPB). Ethical approval for the study was obtained from the Ethics Committee of Paraiba State University.

Data analysis followed the Hays model of diverse individual competency (MARQUES, 1991), according to which all pertinent information about the research subject is taken into consideration, even if a particular opinion or concept was expressed only by a single interviewee.

A t-test was performed in order to determine if significant differences in termite knowledge existed due to gender or age of participants, taking into consideration the number of times that a particular response was given to any question. BIOSTAT 5.0 software was used data analysis.

FIGURE 2: Photographs of different termite species and other insect taxa presented to interviewees in Pocinhos and Fagundes in Paraíba state, NE Brazil.

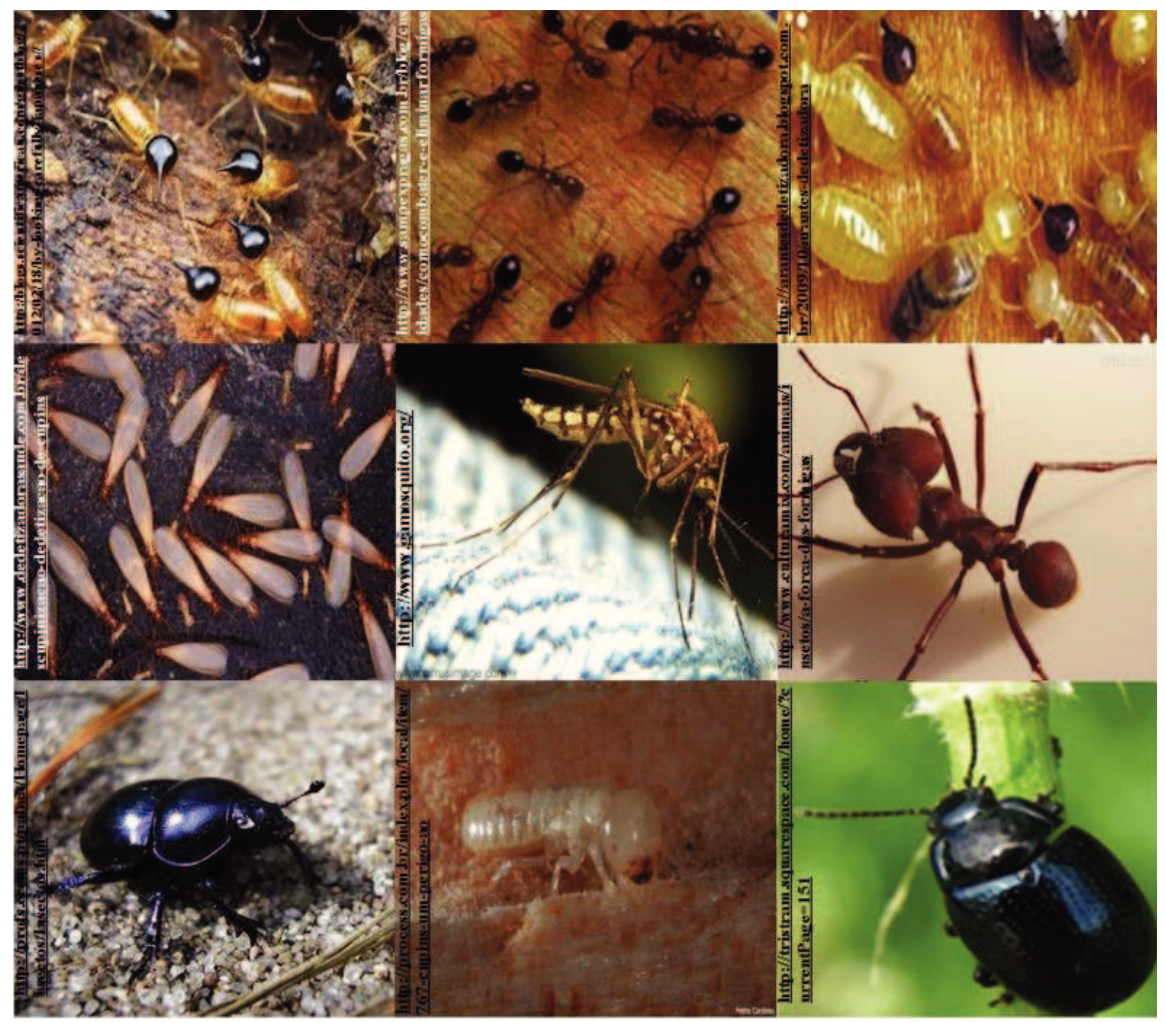




\section{Results}

One hundred percent of the interviewees in the Fagundes municipality $(\mathrm{n}=50)$ indicated that they could visually recognize termites, although only $64 \%(n=$ 32) correctly identified these insects when examining the photographs. The greatest recognition frequency was among women between 59 and 79 years old, and among men between 39 and 59 (Table 1). In the Pocinhos municipality, $98 \%(n=49)$ of the interviewees indicated that they could visually identify termites. Only one woman indicated that she could not identify them (Table 1), and $72 \%$ of the interviewees $(n=36)$ correctly recognized these insects during photograph examination. The greatest recognition frequency in Pochinos was observed among men and women between the ages of 19 and 39 years old.

TABLE 1: Total numbers of individuals who were able to recognize termites (Isoptera, Insecta) by their morphologies in the Fagundes and Pocinhos municipalities, Paraíba state, NE Brazil.

\begin{tabular}{|c|c|c|c|c|c|}
\hline \multirow{2}{*}{ Classes } & \multirow{2}{*}{ Age } & \multicolumn{2}{|c|}{ Fagundes } & \multicolumn{2}{|c|}{ Pocinhos } \\
\hline & & Women & Men & Women & Men \\
\hline 1 & 19 to 39 & 5 & 8 & 13 & 16 \\
\hline 2 & 40 to 59 & 9 & 12 & 5 & 6 \\
\hline 3 & 60 to 79 & 10 & 5 & 6 & 3 \\
\hline \multirow[t]{2}{*}{4} & 80 to 99 & 1 & 0 & 0 & 0 \\
\hline & & 25 & 25 & $24 *$ & 25 \\
\hline
\end{tabular}

Note: * One woman could not recognize the termites.
Most of the interviewees classified termites correctly as insects and, from a psychological point of view, $22 \%(\mathrm{n}=11)$ of the interviewees in Fagundes and $8 \%(n=4)$ in Pocinhos demonstrated some type of aversion to these animals, believing them to be bad, foul smelling, and containing pus. They also believed that termites were detrimental to human health and could even cause death, as seen in the following quotations:

... "they bring death, they bring bad things" (interviewee \# 03, female, age 48);..." bad for your health" (interviewee \# 06, male, age 23);... " a pest that infects the world", comparing them to fleas, ticks, lice and ants (interviewee \# 09, male, age 53); ... "termites are the most destructive creatures in the world" (interviewee \# 11, male, age 57).

Additionally, the interviewees classified termites as "bad because they eat everything; finish off everything", cited by nine people, six women (\# 01, 74 years old, \# 02,76 years old, \# 03, 76 years old, \# 04, 66 years old, \# 06, 52 years old, and \# 08, 42 years old), and three men (\# 02, 62 years old, \# 11, 30 years old, and \# 23, 27 years old); "small creatures that look like ants" was mentioned by three men (\# 24, 29 years old, \# 12, 34 years old and \# 03, 78 years old) and one woman (\# 09, 41 years old); "a bug that's not worth anything" was also expressed by one woman (\# 23, 24 years old).

FIGURE 3: Interviewee perception of termite habitats in Fagundes and Pochinos municipalities, Paraíba state, NE Brazil.

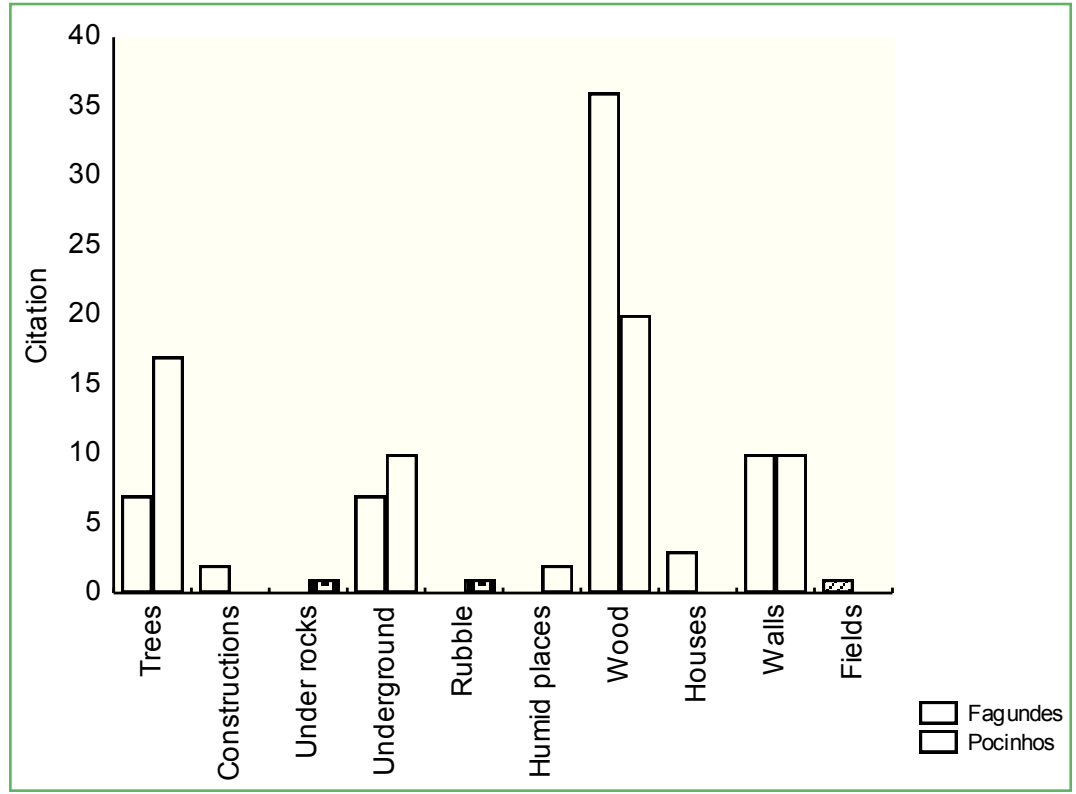


The interviewees in both localities cited in total ten types of habitat or nesting sites for termites (Figure 3 ), with "wood" being most frequently mentioned by both genders, followed by "trees", "walls" and "below the ground". In Pocinhos, the men apparently retained better knowledge of termites' habitats ( 44 citations) than women (37 citations), although these differences were not statistically significant (Fagundes: $\mathrm{t}=0.00 ; \mathrm{p}=0.50$; Pocinhos: $\mathrm{t}=-0.55 ; \mathrm{p}=0.29$ ).

In spite of the fact that the interviewees demonstrated aversion to termites and generally avoided their presence, some of the interviewees showed limited knowledge of the utility of these insects (and/or their nests) for medicinal purposes. In Fagundes, 20\% of the interviewees demonstrated some knowledge of the use of these insects to treat human diseases; in Pocinhos, $36 \%$ of the interviewees had similar knowledge. Women demonstrated a greater overall knowledge of the medicinal use of termites (12 across both areas).

Eight types of diseases, with 10 citations in Fagundes and 18 in Pocinhos, were said to be treated with termites and/or their nests. In the former municipality, coughing and pneumonia were the illnesses most mentioned, with each infirmity representing $10.7 \%$ of the citations (Figure 4); in the latter municipality, coughing was the most commonly cited infirmity (25\%), followed by bronchitis (21.4\%) and asthma (10.7\%) (Figure 4). In Fagundes, a medicinal syrup used for treatment of coughing and influenza is prepared from termite nests constructed in cashew nuts trees (Anacardium occidentale L.). Descriptions of the nests (provided the interviewees) suggest that they belong to termites of the genus Nasutitermes.

In terms of eliminating termites, ten techniques were cited in Fagundes and eight in Pocinhos, with heavy reliance on the use of kerosene to treat infested wooden objects, followed by the application of insecticides and finally used motor oil (Figure 5).

Only $30 \%(n=15)$ of the interviewees in Pocinhos indicated that the techniques used to combat termites were actually effective, and $18 \%(n=9)$ noted that termite control is usually only partial, and for a limited period of time. Fifty-two percent $(n=26)$ of the interviewees stated that there was no truly effective method for controlling termite infestations.

FIGURE 4: Percentage of illnesses treated using termites and/or their nests according to the residents of Fagundes and Pocinhos, Paraíba state, NE Brazil.




FIGURE 5: Termite elimination techniques used in the towns of Fagundes and Pocinhos, Paraíba state, NE Brazil.

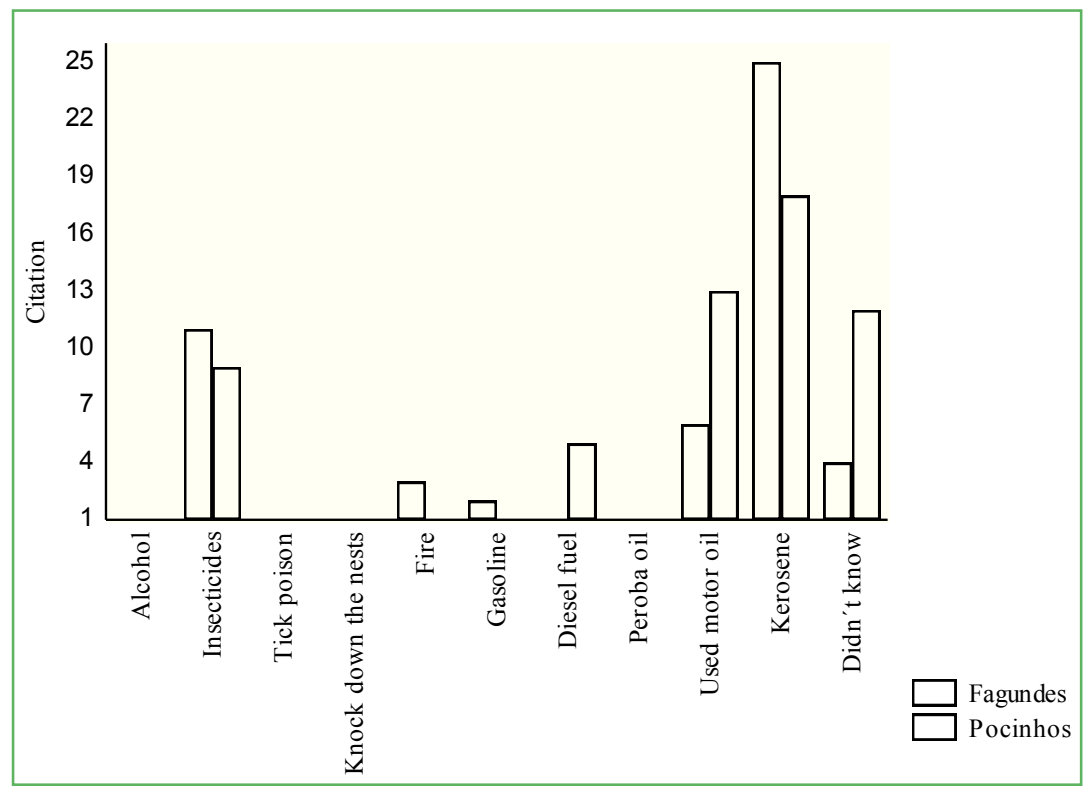

\section{Discussion}

The interviewees viewed termites as containing pus, or as "ticks" that cause harm, or even bring bad luck; these insects are considered repugnant and people associate them with other animals that provoke nausea, extreme dislike, and bad fortune. According to Ferreira (1988), ticks are equated with filth and highly undesirable locations. As such, termites provoked in the interviewees images of unclean environments, places to be avoided or places that were cursed. In general, people have assigned aesthetic and morphological qualities to insects in a non-scientific and anthropomorphic manner (SOUZA JUNIOR et al., 2014).

A number of studies have shown that people do recognize termites as a type of "insect" (MODRO et al., 2009; REZENDE, 2010), although in one study undertaken by Ulysséa et al. (2010), Nasutitermes sp. (Termitidae, Nasutitermitinae) was not recognized by any of the informants. This result was probably due in part to the difficulty in distinguishing flying ants from flying termites. Hoyt and Schultz (1999) noted that as humans progressively distance themselves from the natural world, they lose the ability to distinguish one insect from another, ultimately retaining only negative feelings toward them that are generalized to essentially all insects. These results were similar to other published studies, and indicate a lack of detailed knowledge about these and other insects among the general urban human population (RIBEIRO; MARÇAL JÚNIOR, 1996; COSTA-NETO; PACHECO, 2004; SILVA; COSTANETO, 2004; SOUZA JUNIOR et al., 2014).

The perceptions of the interviewees about the bioecological roles of termites in nature were always negative, likely a result of near total lack of information regarding these animals. Bezerra-Gusmão et al. (2010), in a study undertaken in Campina Grande, Paraiba state, Brazil, confirmed the aversion of local human populations to the presence of termites in their residences, as well as the belief that these insects would bring disgrace and force them to move. However, there are no reports in the literature attributing any human illnesses or allergies to termites (BERTI-FILHO; FONTES, 1996).

Wood was most frequently cited as the natural habitat of termites, even without the interviewees having any technical knowledge of the fact that termites feed principally on cellulose, the predominant component of wood. Bezerra-Gusmão et al. (2010) indicated that the population in Campina Grande knew that termites use wood (and its derivatives) for shelter and as a food source, in agreement with the perceptions of 
the interviewees in the present study. Therefore, the perception that termites are undesirable insects because they eat everything and destroy everything must be largely derived from the visible damage they cause to wood. The common perception that termites live below ground is related to the fact that the urban dwellers consulted in the present study were largely farmers, who would have observed termites in the field. According to Drews (2002), attitudes about animals are formed by our values, knowledge, and perceptions, as well as by the nature of our relationships with them.

Zootherapeutic products are used throughout the world, and Brazil is no exception. Zootherapy is widely practiced by many social classes, primarily in the northeastern region of the country, with insects often being incorporated into popular medicines (COSTANETO, 1999; ALVES et al., 2007; 2011; COUTINHO et al., 2009; SANTOS; LIMA, 2009; LIMA; SANTOS, 2010). Alves (2009) noted that predominantly rural areas typically show greater accumulation of knowledge concerning animals. This observation was supported in the present study, as most of the interviewees claiming termite knowledge had once lived in rural regions.

The use of zootherapeutic products is based on the idea that biologically active substances are present in animal bodies, representing potential natural medicines that can be effective in many situations. Such substances include compounds that can kill cancerous cells, proteins that inhibit blood coagulation, and enzymes that can degrade pesticides, peptides, and microbial toxins (COSTA-NETO; PACHECO, 2004). Coutinho et al. (2010) found that natural products derived from the termite Nasutitermes corniger (Motschulsky, 1855 ) could, in combination with kanamycin, combat infections caused by multi-resistant bacteria.

Fragments of termite nests, or the crushed insects themselves, have also been reported in examples of entomotherapy for treating colds, umbilical hernias in infants, asthma, bronchitis, chest congestion, coughing, sore throats, sinus problems, tonsillitis, stroke and hoarseness in the Brazilian states of Bahia, Alagoas, Pará, and Paraíba (LAGES FILHO, 1934; BRANCH; SILVA, 1983; COSTA-NETO; PACHECO, 2004; SANTOS; LIMA, 2009; ALVES; ROSA, 2013). In Bahia state, the nests of termites also carry microbionts of actinomycetes and Bacillus with antimicrobial potential (BOMFIM, 2010). In Zambia, folk healers use Macrotermes spp. and Hodotermes mossambicus (Hagen, 1858) to treat malnutrition in children, as the flying queens of the species are collected and eaten (either raw or partially cooked) (MBATA, 1999).

Regarding the treatment of diseases, this study corroborates the findings of Lenko and Papavero (1996), who noted that termites are considered a panacea for human diseases. The use of animals or animal parts for medicinal purposes is based on traditional knowledge transmitted from generation to generation (POSEY, 1987), usually through oral narrative, and zootherapeutic treatments are principally encountered in localities that do not offer easy access to doctors and pharmaceutical drugs. Natural medicines therefore represent viable alternatives to allopathic drugs as a function of socioeconomic realities, cultural traditions, and local biological diversity (ALVES et al., 2008).

Termite control methods used by the populations of the two municipalities in this study reflect attitudes of despair, aversion, and anxiety concerning the insects, as well as a lack of knowledge about effective eradication techniques. It has been noted that the difficulty in identifying specimens of termites (a pest that must be exterminated) may be associated with the difficulty to eliminate them, as the population categorizes various organisms as termites. According to Costa-Neto and Pacheco (2004), the television and movie industries foster negative attitudes about insects, as films and tv shows rarely project positive images of arthropods. In fact, typical imagery reflects situations of danger or death, or shocking scenes that are designed to provoke fear and panic or, at best, caricatures (anthropomorphisms) of such organisms (MERTINS, 1986). Additionally, basic information is rarely available concerning specialized techniques that can be used to identify and treat termite infestations, including how to recognize which species is causing the damage, how to determine the degree of infestation, and appropriate chemical products or techniques to be employed.

The large scale temporal association of humans with the natural environment has reinforced the view 
that insects are invaders and sources of discomfort; this encourages endless attempts to control them without understanding their important ecological roles (FONTES; BERTI-FILHO, 1998). The elimination of termites, which play essential ecological roles, would simply favor the appearance of other species not originally viewed as pests. Lage (2004) noted that the chemical products employed to control wood-devouring termites in urban situations are used without any real knowledge of their specificity (as was corroborated in the present study). A better knowledge of the biology and ecology of these insects would aid humans in understanding the function of this group of insects in the natural environment, and might gradually modify human interactions with these insects (MORALES et al., 1997; FAIRHEAD; LEACH, 1999; COSTA-NETO; PACHECO, 2004).

Our study indicated that human populations in urban areas are largely unaware of the beneficial roles of termites in the natural environment, and that these insects are viewed as loathsome creatures that can provoke economic damage and feelings of bad luck and repugnance. Therefore, programs are needed in order to better inform people living in both urban and rural situations about these insects, in order to debunk prejudices against them, and to emphasize their critical roles in nature.

In spite of the fact that humans have recognized the utility of termites in medicinal practices, their association with bad fortune and even death is probably responsible for their limited use as zootherapeutic, and these negative associations have been incorporated into sociocultural protocols that are passed from generation to generation.

\section{Acknowledgements}

The authors are grateful to $\mathrm{UEPB} / \mathrm{CNPq}$ (2.05.02.00-1) and the graduate program in Ecology and Conservation at the State University of Paraíba, for technical and financial support. We also thank Dr. Roy Richard Funch for his translation of this manuscript.

\section{References}

ALVES, R. R. N. Uso de invertebrados na medicina popular no Brasil. Caderno de Cultura e Ciência, Juazeiro do Norte, v. 3, n. 1, p. 43-51, 2007.

ALVES, R. R. N. Fauna used in popular medicine in Northeast Brazil. Journal of Ethnobiology and Ethnomedicine, London,v. 5, p. 1-11, 2009.

AlVES, R. R. N.; BARBOSA, J. A. A.; SANTOS, S. L. D. X.; SOUTO, W. M. S.; BARBOZA, R. R. D. Animal-based remedies as complementary medicines in the semi-arid region of northeastern Brazil. Evidence-Based Complementary and Alternative Medicine, Nova York, v. 2011, <http://dx.doi.org/10.1093/ecam/ nep134>.

ALVES, R. R. N.; DIAS, T. L. P. Usos de invertebrados na medicina popular no Brasil e suas implicações para a conservação. Tropical Conservation Science, México, v. 3, n. 2, p. 159-174, 2010.

ALVES, R. R. N.; IERECÊ, L. R.; GINDOMAR, G. S. The role of animal-derived remedies as complementary medicine in Brazil. BioScience, Uberlândia, v. 57, n. 11, p. 949-955, 2007.

ALVES, R. R. N.; ROSA, I. L. From cnidarians to mammals: the use of animals as remedies in fishing communities in NE Brazil. Journal of Ethnopharmacology, Shannon, v. 107, p. 259-276, 2006.

ALVES, R. R. N.; ROSA, I. L. Animals in traditional folk medicine. New York/Dordrecht/London: Springer Berlin Heidelberg, 2013. 491 p.

ALVES, R. R. N.; SILVA, C. C.; ALVES, H. N. Aspectos sócioeconômicos do comércio de plantas e animais medicinais em áreas metropolitanas do Norte e Nordeste do Brasil. Revista de Biologia e Ciências da Terra, Campina Grande, v. 8, n. 1, p. 181-188, 2008. BALlONE, G. J. Percepção e realidade parte 2 curso de psicopatologia. Psiqweb Psiquiatria Geral. 1999. Disponível em: $<$ http:www.psiqweb.med.br/cursos/percep.html $>$. Acesso em: 2 mar. 2002.

BERNARD, R. H. Research methods in Anthropology: qualitative and quantitative approaches. Thousand Oaks: Sage Publications, 1994. 803 p.

BERTI-FILHO, E.; FONTES, L. R. Alguns aspectos atuais da biologia e controle de cupins. Piracicaba: FEALQ, 1996. 99 p.

BEZERRA-GUSMÃO, M. A.; BARBOSA, J. R. C.; BARBOSA, M. R. V.; BANDEIRA, A. G.; SAMPAIO, E. V. S. B. Are nests of Constrictotermes cyphergaster (Isoptera, Termitidae) important in the $\mathrm{C}$ cycle in the driest area of semiarid caatinga in northeast Brazil? Applied Soil Ecology, Amsterdam, v. 47, p. 1-5, 2011.

BEZERRA-GUSMÃO, M. A.; VASCONCELOS, M. E.; ALMEIDA, F. A. O.; BARBOSA-SILVA, A. M.; OLIVEIRA, W. A. Biologia e ecologia de cupins (Isoptera) em área urbana no estado da Paraíba, nordeste do Brasil. Relatório PIBIC/CNPq/ UEPB, Universidade Estadual da Paraíba, 2010. 39 p.

BIGNELL, D. E.; EGGLETON, P. Termites in ecosystems. In: ABE, T., BIGNELL, D. E.; HIGASHI, M. (Ed.) Termites: evolution, sociality, symbioses, ecology. Netherlands: Kluwer Academic Publishers, 2000. p. 363-387.

BRANCH, L.; SILVA, M. F. Folk medicine of Alter do Chão, Pará, BR. Acta Amazonica, Manaus,v. 13, n. 5-6, p. 737-797,1983. 
BOMFIM, G. F. Atividade antimicrobiana de microrganismos isolados de cupinzeiros da região da mata de cipó, Bahia. 2010. 70 f. Dissertação (Mestrado em Biotecnologia) - Universidade Estadual de Feira de Santana, Feira de Santana. 2010.

COSTA-NETO, E. M. Etnoentomologia alagoana, com ênfase na utilização medicinal de insetos. Relatório $\mathrm{PIBIC} / \mathrm{CNPq}$, Universidade Federal de Alagoas, Maceió, 1994. 54 p.

COSTA-NETO, E. M. Etnotaxonomia zoológica do grupo indígena Pankararé do Raso da Catarina, Bahia. In: ENCONTRO DE ZOOLOGIA DO NORDESTE, XI, 1997, Fortaleza. Resumos... Fortaleza: EZN, 1997. p. 126.

COSTA-NETO, E. M. Folk taxonomy and cultural significance of "abeia" (Insecta, Hymenoptera) to the Pankararé, Northeastern Bahia State, Brazil. Journal of Ethnobiology, Washington, v. 18, n. 1, p. 1-13, 1998.

COSTA-NETO, E. M. Etnocategoria "inseto" e a hipótese da ambivalência entomoprojetiva. Acta Biologica Leopoldensia, São Leopoldo, v. 21, n. 1, p. 7-14, 1999.

COSTA-NETO, E. M. Manual de Etnoentomología. Zaragoza: Editora Zaragoza, 2002. 104 p.

COSTA-NETO, E. M. Estudos entomológicos no estado da Bahia, Brasil: uma homenagem aos 50 anos do campo de pesquisa. Biotemas, Florianópolis, v. 17, n. 1, p. 117-149, 2004.

COSTA-NETO, E. M.; PACHECO, J. M. A construção do domínio etnozoológico "inseto" pelos moradores do povoado de Pedra Branca, Santa Terezinha, estado da Bahia. Acta Scientiarum. Biological Science, Maringá, v. 26, n. 1, p. 81-90, 2004.

COUTINHO, H. D. M.; VASCONCELLOS, A.; FREIRE-PESSÔA, H. L.; GADELHA, C. A.; GADELHA, T. S.; ALMEIDA-FILHO, G. G. Natural products from the termite Nasutitermes corniger lowers aminoglycoside minimum inhibitory concentrations. Pharmacognosy Magazine, Mumbai, v. 6, n. 21, p. 1-4, 2010.

COUTINHO, H. D. M.; VASCONCELlOS, A.; LIMA, M. A.; ALMEIDA-FILHO, G. G.; ALVES, R. R. N. Termite usage associated with antibiotic therapy: enhancement of aminoglycoside antibiotic activity by natural products of Nasutitermes corniger (Motschulsky 1855). BMC Complement Altern Med, London, v. 9, n. 35, p. 1-4, 2009.

DREWS, C. Attitudes, knowledge and wild animals as pets in Costa Rica. Anthrozoös, California, v. 15, n. 2, p. 119-138, 2002.

FAIRHEAD, J.; LEACH, M. Termites, society and ecology: perspectives from West Africa. In POSEY, D. A. (Ed.). Cultural and spiritual values of biodiversity. London: UNEP and Intermediate Technology Publications, 1999. p. 235-242.

FERREIRA, A. B. H. Dicionário Aurélio básico da Língua Portuguesa. 4 impressão. Rio de Janeiro: Ed. Nova Fronteira, $1988.687 \mathrm{p}$.

FONTES, L. R.; BERTI-FILHO, E. Cupins, o desafio do conhecimento. Piracicaba: FEALQ, 1998. 511 p.

HOYT, E.; SCHULTZ. T. Insectlives: stories of mystery and romance from a hidden world. New York: John Wiley \& Sons, 1999. $360 \mathrm{p}$.

IBGE - INSTITUTO BRASILEIRO DE GEOGRAFIA E ESTATÍSTICA. Dados 2010. Disponível em: <http://www. censo2010.ibge.gov.br/dados_divulgados/index.php?uf=25>. Acesso em: 8 mar. 2011.
JODELET, D. La representación social: fenómenos, conceptos y teoria. In: MOSCOVICI, S. (Ed). Psicología social. 2 ed. Paris: PUF, 1988. p. 357-378.

LAGE, M. C. G. Eficiência de inseticidas para preservar madeira contra danos de cupim subterrâneo. Rio de Janeiro: Seropédica, 2004. $61 \mathrm{p}$.

LAGES-FILHO, J. A medicina popular em Alagoas. Salvador: Instituto Nina Rodrigues, 1934. 27 p.

LAUCK, J. E. The voice of the infinite in the small: revisioning the insect-human connection. Boston: Shambhala Publications, 2002. $256 \mathrm{p}$.

LENKO, K.; PAPAVERO, N. Insetos no folclore. São Paulo: Conselho Estadual de Artes e Ciências Humanas, 1996. 446 p.

LIMA, J. R. B; SANTOS, C. A. B. Recursos animais utilizados na medicina tradicional dos índios Pankararu no nordeste do estado de Pernambuco, Brasil. Etnobiología, México, v. 8, p. 39-50, 2010.

MARQUES, J. G. W. Aspectos ecológicos na etnoictiologia dos pescadores do complexo estuarino-lagunar MundaúManguaba. 1991. 297 f. Tese (Doutorado em Ecologia) Universidade Estadual de Campinas, Campinas. 1991.

MBATA, K. J. Traditional uses of arthropods in Zambia: II. Medicinal and miscellaneous uses. The Food Insects Newsletter, Bozeman, v. 12, n. 2, p. 1-7, 1999.

MERTINS, J. W. Arthropods on the screen. Bulletin of the Entomological Society of America, Palo Alto, v. 32, p. 85-90, 1986.

MILANO, S.; FONTES, L. R. Termite pests and their control in urban Brazil. Sociobiology, California,v. 40, n. 1, p. 163-177, 2002.

MODRO, A. F. H.; COSTA, M. S.; MAIA, E.; ABURAYA, F. H. Percepção entomológica por docentes e discentes do município de Santa Cruz do Xingu, Mato Grosso, Brasil. Biotemas, Florianópolis, v. 22, n. 2, p. 153-159, 2009.

MORALES, A. G.; SILVA, V. C.; SILVA, N. F. Estudo comparativo das atitudes de estudantes de Assis, SP, frente aos animais invertebrados. In: JORNADA DE EDUCAÇÃO, 4, 1997, Assis. Resumos... Assis: Unesp, 1997. p. 2.

MOSCOVICI, S. EI psicoanálisis, su imagen y su público. Buenos Aires: Huemul S.A., 1979. 366 p.

NOBREGA, V. A.; BARBOSA, J. A. A.; AlVES, R. R. N. Utilização de aves silvestres por moradores do município de Fagundes, Semiárido paraibano: uma abordagem etno-ornitológica. Sitientibus, Série Ciências Biológicas, Feira de Santana, v. 11, n. 2, p. 165-175, 2011.

NUNEZ, I. B.; RAMALHO, B. L.; UEHARA, F. M. G. As teorias implícitas sobre a aprendizagem de professores que ensinam Ciências Naturais e futuros professores em formação: a formação faz diferença? Ciências \& Cognição, Rio de Janeiro, v. 14, n. 3, p. 39-61, 2009.

PERONTI, A. L. B. G.; NARDY, R. M. C.; AYRES, O. M.; RONQUIM, J. C.; RONQUIM, C. C. Percepção ambiental da população de São Carlos (SP) sobre os insetos. In: SIMPÓSIO BRASILEIRO DE ETNOBIOLOGIA E ETNOECOLOGIA, 2, 1998, São Carlos. Anais... São Carlos: UFSCar, 1998. p. 98.

POSEY, D. A. Etnoentomologia de tribos indígenas da Amazônia. In: RIBEIRO, B. G. (Ed.). Suma Etnológica Brasileira. Petrópolis: Editora Vozes, 1986. p. 251-273. 
POSEY, D. A. Temas e inquirições em etnoentomologia: algumas sugestões quanto à geração de hipóteses. Boletim do Museu Paraense Emílio Goeldi, Belém, v. 3, n. 2, p. 99-134, 1987.

REZENDE, M. Q. Etnoecologia e controle biológico conservativo em cafeeiros sob sistemas agroflorestais. 2010. $83 \mathrm{f}$. Dissertação (Mestrado em Entomologia) - Universidade Federal de Viçosa, Viçosa. 2010.

RIBEIRO, R. S. Pocinhos: o local e o geral. Campina Grande: RG Gráfica e Editora, 2003. 164 p.

RIBEIRO, S. C.; MARÇAL JÚNIOR, O. Aspectos da taxonomia popular de artrópodos, na comunidade de Cruzeiro dos Peixotos (Uberlândia - MG) I. Identificação e nomenclatura. Revista do Centro de Ciências Biomédicas da Universidade Federal de Uberlândia, Uberlândia, v. 12, n. 1, p. 13-18, 1996.

SAMPAIO, F. A. C.; TEIXEIRA, P. M. M.; JUCÁ-CHAGAS, R.; BOCCARDO, L. Os peixes e a pesca. Concepções dos estudantes do povoado de Porto Alegre, Maracás, Bahia, Brasil. Sitientibus, Série Ciências Biológicas, Feira de Santana, v. 6, p. 44-56, 2006.

SANTOS, C. A. B; LIMA, J. R. B. Estudo Etnozoológico: o comércio de produtos de origem animal utilizados como produtos farmacológicos nas cidades de Paulo Afonso-BA e Delmiro Gouveia-AL. Ouricuri, Paulo Afonso, v. 1, n. 1, p. 115-128, 2009.
SILVA, T. F. P.; COSTA-NETO, E. M. Percepção de insetos por moradores da comunidade Olhos D’Água, município de Cabaceiras do Paraguaçu, Bahia, Brasil. Boletín de la Sociedad Entomológica Aragonesa, Aragão, v. 35, p. 261-268, 2004.

SOUZA JUNIOR, E. A.; COSTA NETO, E. M.; SANTOS, G. C. B. As concepções que estudantes da sexta série do ensino fundamental do Centro de Educação Básica da Universidade Estadual de Feira de Santana possuem sobre os insetos. Gaia Scientia, João Pessoa, v. 8 , n. 1 , p. $8-16,2014$

SU, N. Y.; SCHEFFRAHN, R. H. Economically important termites in the United States and their control. Sociobiology, Chico, v. 17, n. 1, p. 77-94, 1990.

SUDENE - SUPERINTENDÊNCIA DO DESENVOLVIMENTO DO NORDESTE. Dados pluviométricos mensais do nordeste: Paraíba. Recife: SUDENE, 1990. 239 p.

TREVISAN, H. J.; NADAI, A. M. L.; CARVALHO, A. G. Ocorrência de térmitas subterrâneos (Isoptera: Rhinotermitidae e Termitidae) e durabilidade natural da madeira de cinco essências florestais. Ciência Florestal, Santa Maria, v. 13, n. 2, p. 153-158, 2003.

ULYSSÉA, M. A.; HANAZAKI, N.; LOPES, B. C. Percepção e uso dos insetos pelos moradores da comunidade do Ribeirão da Ilha, Santa Catarina, Brasil. Biotemas, Florianópolis, v. 23, n. 3, p. 191-202, 2010. 